\title{
Correction to: Versatility of algae-exploring the potential of algae for nutrient circulation
}

\author{
Anja Kuenz • Daniel Grimm • Gerold Rahmann
}

Published online: 28 August 2021

(C) The Author(s) 2021

\author{
Correction to: Org. Agr. (2021) 11:251-260 \\ https://doi.org/10.1007/s13165-020-00308-0
}

The article "Correction to: Versatility of algaeexploring the potential of algae for nutrient circulation", written by Anja Kuenz, Daniel Grimm, and Gerold Rahmann, was originally published Online First without Open Access. After publication in volume 11, issue 2, pages 251-260, the author decided to opt for Open Choice and to make the article an Open Access publication. Therefore, the copyright of the article has been changed to (C) The Author(s) 2021 and the article is forthwith distributed under the terms of the Creative Commons Attribution 4.0 International License, which permits use, sharing, adaptation, distribution, and reproduction in any medium or format, as long as you give appropriate credit to the original author(s) and the source, provide a link to the Creative Commons licence, and indicate if changes were made. The images or other third party material in this article are included in the

The original article can be found online at https://doi.org/ 10.1007/s13165-020-00308-0.

\section{A. Kuenz $(\square)$}

Thünen-Institute of Agricultural Technology,

Braunschweig, Germany

e-mail: anja.kuenz@thuenen.de

D. Grimm · G. Rahmann

Thünen-Institute of Organic Farming, Trenthorst, Germany article's Creative Commons licence, unless indicated otherwise in a credit line to the material. If material is not included in the article's Creative Commons licence and your intended use is not permitted by statutory regulation or exceeds the permitted use, you will need to obtain permission directly from the copyright holder. To view a copy of this licence, visit http://creativecommons.org/licenses/by/4.0/.

The original article has been corrected.

Open Access This article is licensed under a Creative Commons Attribution 4.0 International License, which permits use, sharing, adaptation, distribution and reproduction in any medium or format, as long as you give appropriate credit to the original author(s) and the source, provide a link to the Creative Commons licence, and indicate if changes were made.

The images or other third party material in this article are included in the article's Creative Commons licence, unless indicated otherwise in a credit line to the material. If material is not included in the article's Creative Commons licence and your intended use is not permitted by statutory regulation or exceeds the permitted use, you will need to obtain permission directly from the copyright holder.

To view a copy of this licence, visit http://creativecommons. org/licenses/by/4.0/.

Publisher's note Springer Nature remains neutral with regard to jurisdictional claims in published maps and institutional affiliations. 